\title{
Effects of Biochar and Farm Yard Manure on Soil Properties and Crop Growth in an Agroforestry System in the Himalaya
}

\author{
Deepak K. Gautam ${ }^{1,2}$, Roshan M. Bajracharya ${ }^{2} \&$ Bishal K. Sitaula $^{3}$ \\ ${ }^{1}$ Nepal Agroforestry Foundation (NAF), PO Box 9594, Amarawatimarg 35, Koteshwor, Kathmandu, Nepal \\ ${ }^{2}$ Department of Environmental Science and Engineering, Kathmandu University, PO Box 6250, Dhulikhel, \\ Nepal \\ ${ }^{3}$ Department of International Environment and Development Studies (Noragric), Norwegian University of Life \\ Sciences (NMBU), PO Box 5001, N-1432 As, Norway \\ Correspondence: Deepak K. Gautam, Nepal Agroforestry Foundation (NAF), PO Box 9594, Amarawatimarg , \\ Koteshwor, Kathmandu, Nepal. E-mail: deepak.gautamjee@gmail.com
}

Received: July 5, 2017 Accepted: August 8, 2017 Online Published: August 28, 2017

doi:10.5539/sar.v6n4p74 URL: https://doi.org/10.5539/sar.v6n4p74

\begin{abstract}
Many parts of South Asia are facing agricultural land degradation and reduced productivity while the population continues to grow and demand for food is ever-increasing. This paper presents the results of research specifically focused on application of biochar and Farm Yard Manure (FYM) at 5t/ha and 20t/ha, respectively as an amendment on degraded soil in a coffee agroforestry system of the mid-hills in the Nepal Himalaya. The study showed that there were significant $(\mathrm{P}<0.05)$ positive effects on soil chemical properties, crop growth (height) and crop productivity. In particular, the soil $\mathrm{pH}$ and $\mathrm{SOM}$ increased significantly, while other soil properties were not significantly improved. Also, plant growth increased dramatically with application of biochar, however, crop yields showed only slight increases. It is suggested that biochar applied at low rates along with FYM generally has immediate positive effects on the vegetative growth of plants, however, soil properties and overall crop yields may take a longer time to show improvement.
\end{abstract}

Keywords: soil quality, soil fertility, organic matter, plant height, crop yield

\section{Introduction}

Agricultural land degradation is an alarming environmental and economic problem in the Himalaya. It is the result of soil erosion, nutrient mining, soil compaction and increased soil acidity levels (Neupane, 2000., Tiwari et al., 2006., Schreier et al.,1994., Bajracharya \& Sherchan 2009). Soil analysis is an important precursor to evaluate the major soil chemical properties such as soil $\mathrm{pH}$, soil organic carbon (SOC), bulk density (BD), soil total nitrogen (TN), available phosphorus (AP), exchangeable potassium (EK), and cation exchange capacity (CEC) Tiwari et al., 2006). Soil biophysical and chemical quality is critically important for sustaining the crop productivity and protecting the environment. According to Liu \& Ma, (2009) soil microorganisms are vital for maintaining the soil fertility and enhancing crop productivity to meet the food demands of an ever- increasing global population. Similarly Rasul \& Thapa, (2004) reported that to enhance the soil's biological fertility, promotion of leguminous crop cultivation, agroforestry and livestock farming are good approaches.

Bajracharya, \& Sherchan, (2009); Balla et al., (2014) described that mountain farmers of Nepal are heavily dependent on forest based farming system to sustain their livelihoods. As most of them have no alternatives except the natural resource base to fulfill their subsistence requirements such as food, fodder, fuel wood, fiber, construction materials and other non-wood forest products. Due to this, land and forest resources are gradually becoming degraded over the period of several decades. The process of land degradation is a consequence of soil erosion by water and wind, degradation of forest and grazing lands and inadequate conservation measures on sloping agricultural terrain. Similarly, there are other factors such as use of chemical fertilizer, reduced application of farmyard manure on the agricultural land and commercialized intensive cropping to maximize profits. There is an urgent need to maintain and augment soil fertility by applying organic matter, particularly adequate amounts of farm yard manure, crops residues and bio-fertilizer on agricultural soils (Swanepoel et al., 2015). 
The findings of numerous studies have indicated that biochar could be a viable amendment to enhance soil physical and chemical properties (Ścisłowska et al., 2015). Biochar is a carbon rich substance produced by incomplete pyrolysis process of organic materials such as wood, leaves, crop residues and manure after heating in a closed container (at temperatures ranging from 300 to 500 degrees Celsius) in an oxygen restricted condition (Yu et al., 2013). Biochar can be incorporated into soil for improving soil productivity, carbon sequestration and water retention (Novak et al., 2012). Boichar is not a compost material, rather, it is a catalyst of soil microbial activity which augments soil chemical properties and enhances soil water storage capacity to increase crop productivity (Steiner et al., 2007., Lehmann \& Joseph, 2015., Liu 2012., Mekuria et al., 2013 and Akhter et al., 2014).

The chemical properties of biochar vary with different kinds of feedstock, methods of preparation and technologies used for production. Alburquerque et al., (2013) recommended that application of biochar to soils can contribute to climate change mitigation and adaptation by improving management of waste materials arising from the agriculture and forestry sectors, as well as locking carbon in a long-term sink in the soil. The authors further argued that biochar can largely influence soil properties such as $\mathrm{pH}$, electrical conductivity and resinextractable phosphate and effects plant growth and grain production. It also enhances environmental benefit, global warming mitigation and contributes positively to sustainable agriculture. Yu et al., (2013) reported that use of woody biochar made from yellow pine in North Carolina, USA, applied to loamy sand soil at high rates resulted in remarkably increased water holding capacity. This study also recommended that biochar could help to significantly mitigate climate change while simultaneously increasing crop production and supporting sustainable agriculture.

Another land use strategy that also holds good potential for rural communities, especially hill farmers, to mitigate and adapt to climate change is agroforestry. Agroforestry practices provide a number of benefits to rural communities such as food security; household income; economic stability and shelter are often associated with their products such as fruit, timber, and other items (Kandji et al., 2003 and Roshetko et al. 2002). These practices are recognized as effective approaches for maintaining and improving soil fertility by providing organic carbon, total nitrogen, microbial biomass, basal respiration and activity of soil enzyme (Tian et al., 2013 and Udawatta et al. 2014). Agroforestry has the potential to protect land degradation and improve the soil productivity by incorporating woody perennial based mixed cropping system through interaction among trees, soils, crops and livestock (Kumar, 2006). Moreover, it provides a number tangible benefits for local adaptation such as income from carbon, wood energy, improvement of soil quality, ecosystem services, and reduces human impact on forests thereby contributing to global efforts to reduce atmospheric greenhouse gas emissions (Mbow et al.,2014., Udawatta et al., 2014 and Nair, 2012). Thus, agroforestry has been acknowledged within the Kyoto Protocol as well as other international conventions, such as, the UNFCCC and CBD for it potential to contribute both to sustainable development along with carbon sequestration and climate change mitigation and adaptation (Kandji et al., 2003; Nair et al., 2009; Jose \& Bardhan, 2012 and Pastur et al., 2012).

The objective of this study was, therefore, to evaluate the use of biochar produced from locally available weed/leaf-litter biomass applied to soil in a hill agroforestry cropping system to determine its effects on soil properties and crop production in the central Nepal Himalaya.

\section{Materials and Methods}

\subsection{Site Description and Soil Sampling}

The field trials were carried out at Sharswotikhel in Bhaktapur district $\left(27^{\circ} 41^{\prime} 41.39^{\prime \prime} \mathrm{N}, 85^{\circ} 24^{\prime} 11.59^{\prime \prime} \mathrm{E}\right.$, altitude 1,372 m.a.s.l) of Nepal. The study site was located $12 \mathrm{Km}$ north-east of Kathmandu city where the climate is sub-tropical with an annual rainfall of about $1500 \mathrm{~mm}$. The research trial was established within a coffee agroforestry system where other crops like radish, soybean, garlic and chilly were intercropped in different seasons with coffee plant. Plant heights were measured on a fortnightly or monthly basis depending on the crop growth rate. An experimental plot with a total area of $36 \mathrm{~m}^{2}$ was divided in to two blocks, namely, a control (without biochar) and treatment (biochar applied at $5 \mathrm{t} / \mathrm{ha}$ ). The soil samples were taken in February, 2014, from $0-15 \mathrm{~cm}$ and $15-30 \mathrm{~cm}$ depths to examine the baseline status of soil nutrient levels and physico-chemical quality. Soil samples were collected from 4 randomly selected locations within each plot. The soil samples were kept in labeled and sealed plastic bags and transported to the Aquatic Ecology Center (AEC) Soil and Water Laboratory at Kathmandu University, Dhukilhel for processing and analyses.

For laboratory analysis all samples were air-dried, ground and passed through a $2 \mathrm{~mm}$ sieve for soil physical and chemical analysis. The soil physical and chemical properties were determined using USDA standards methods: soil texture by the Bouypucous hydro meter method (Gee \& Bauder, 1986), pH using probe method ( McLean 
1982), bulk density (BD) dry combustion method (Blake \& Hartge, 1986), soil organic matter (SOM) dry combustion method (Nelson \& Sommere, 1982), total nitrogen (TN) by Kjeldahl method (Bremner \& Mulvaney, 1982), available phosphorus (AP) by modified Olsen's method (Olsen \& Sommers, 1982), exchangeable potassium (EK) by ammonium acetate extraction followed by AAS method and cation exchange capacity (CEC) by ammonia acetate extraction method (Rhoades, 1982).

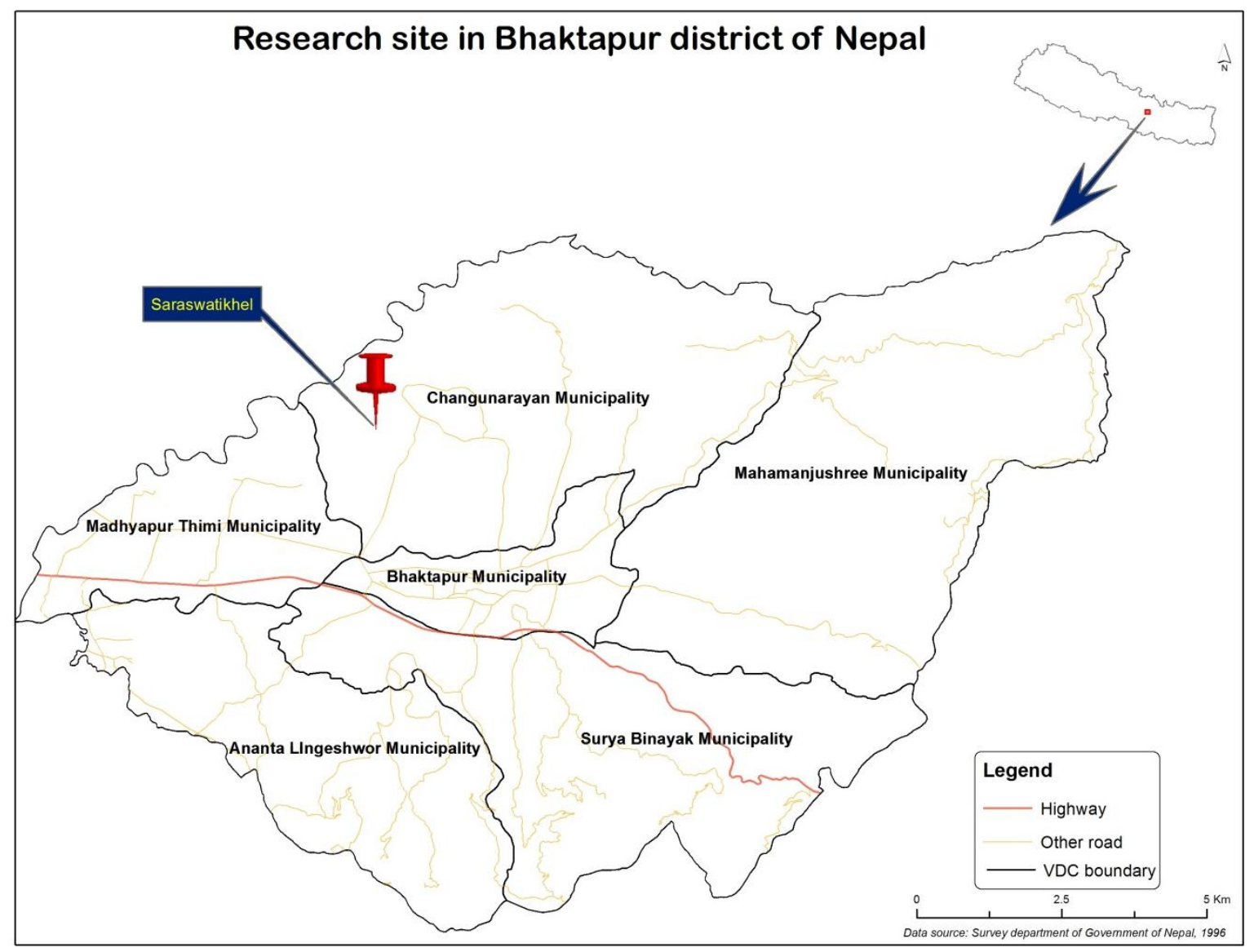

Figure 1. Map and location of the research site

\subsection{Statistical Analysis}

Results obtained from measurement of soil physical and chemical properties, plant growth and production were analyzed by use of Minitab 17 software. The inferential differences were determined significant at a 5\% level of significance $(\mathrm{p}<0.05)$. The paired " $\mathrm{t}$ " test was employed for the determination of significance in relationships between crop growths, crop production, soil parameters for baseline, biochar + FYM amended, and, FYM only plots.

\subsection{Application of Biochar and Farm Yard Manure (FYM)}

Biochar and FYM were applied in the field trials at the rate of 5 ton/ha biochar and 20 ton/ha FYM per hectare, respectively. Biochar was produced from locally available feed stocks (grasses and Eupatorium sp.) at $300^{\circ} \mathrm{C}$ to $500^{\circ} \mathrm{C}$ under low pyrolysis process for 3-4 hours, whereas FYM was made from livestock manure including dung and urine mixed with farm and non-farm litter, such as, crop residues, household wastage and leftover fodder and forage grasses/leaves as well as animal bedding materials (straw, leaf-litter, etc.). Biochar characterization was performed at the Soil and Water Analysis Laboratory of the Aquatic Ecology Center (AEC) at Kathmandu University, Dhulikhel. The characterization of biochar is given in table 1. 
Table 1. Chemical properties of biochar

\begin{tabular}{|c|c|c|}
\hline Parameters & Mean Value & Test method/ Instrument employed \\
\hline $\mathrm{pH}$ & 10.76 & Probe method (Mclean, 1982) \\
\hline Soil Organic Matter (SOM)\% & 42.75 & Loss on ignition (Nelson \& Sommers, 1982) \\
\hline Total Nitrogen (ppm) & 420 & Kjeldhal digestion method ( Bremer \& Mulvaney, 1982) \\
\hline Available Phosphorus (ppm) & 5886 & $\begin{array}{l}\text { Dry ash followed by Modified Oslen's method } \\
\text { (Oslen \& Sommers, 1982) }\end{array}$ \\
\hline Available Potassium (ppm) & 820.6 & $\begin{array}{l}\text { Ammonia Acetate extraction followed by AAS } \\
\text { (Knudsen et al., 1982) }\end{array}$ \\
\hline \multicolumn{3}{|c|}{ Micro Nutrients } \\
\hline Iron $(\mathrm{Fe})(\mathrm{mg} / \mathrm{kg})$ & 348.9 & DPTA followed by AAS ( Oslen \& Ellis,1982) \\
\hline Manganese $(\mathrm{Mn})(\mathrm{mg} / \mathrm{kg})$ & 132.8 & DPTA followed by AAS ( Gambrell \& Ellis,1982) \\
\hline Zinc $(\mathrm{Zn})(\mathrm{mg} / \mathrm{kg})$ & 1.27 & DPTA followed by AAS ) ( Baker \& Amacher, 1982) \\
\hline Copper $(\mathrm{Cu})(\mathrm{mg} / \mathrm{kg})$ & 387.5 & DPTA followed by AAS ( Baker \& Amacher, 1982) \\
\hline
\end{tabular}

\subsection{Experimental Design}

The field trial plot was on coffee agroforestry trial with 24 coffee trees planted in three rows with spacing of 1.5 $\mathrm{m}$ between row and $1.5 \mathrm{~m}$ between plants. The plot was divided in to two blocks of $18 \mathrm{~m}^{2}$ each, and biochar was applied randomly two one of the blocks (see figure 2) FYM was applied to both blocks, initially at the rate of 20 t/ha, then during the second season, at a high dose of $40 \mathrm{t} / \mathrm{ha}$ due to the very low SOM status of the soil. Field experiment layout is depicted in figure 2 .

\section{Field Experimental Plot Layout}

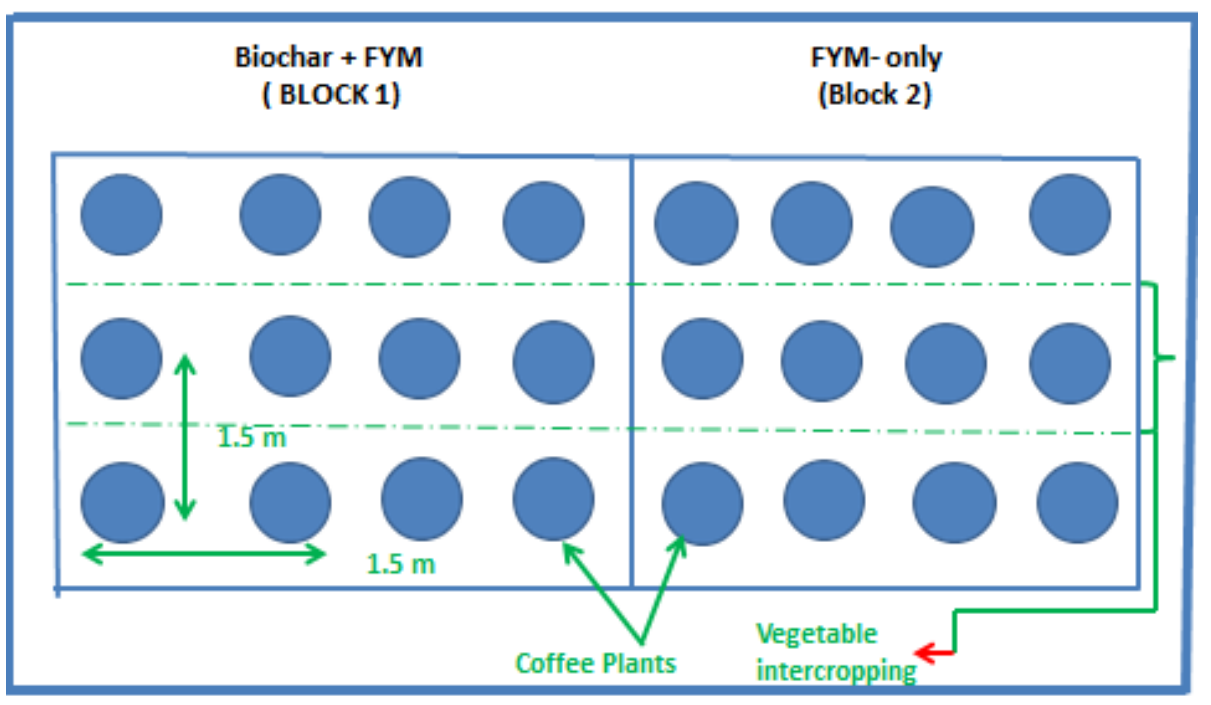

Figure 2. Plot Layout (total area: 36 square meters)

\section{Results}

\subsection{Soil Chemical Properties}

The mean values of soil physical and chemical properties of topsoil (0-15cm) and sub soil (15-30) before biochar application (baseline data), after biochar and FYM amendment and, after only FYM addition are given below in tables 2 and 3.

In case of topsoil, $\mathrm{pH}, \mathrm{SOM}$ and exchangeable potassium $(\mathrm{EK})$ increased significantly $(\mathrm{P}<0.05)$ after biochar and FYM addition to the soil, whereas, Total Nitrogen (TN) and Cation Exchange Capacity (CEC) increased slightly, but were not statistically significantly different between the control and biochar treatment. In contrast, available phosphorus (AP) decreased significantly $(\mathrm{P}<0.05$, Table 2$)$. 
The topsoil of biochar and FYM amended and only FYM added plots showed higher pH, exchangeable potassium and CEC in biochar-cum-FYM amended soils compare to only FYM added soils with no statistical significance. Whereas, SOM and AP were observed high in only FYM added soils. The TN, was also observed to be somewhat higher in the FYM only plot compared to biochar +FYM soils, but not significantly different (Table 2).

Table 2. Mean values ( \pm std. dev.) of top soil $(0-15 \mathrm{~cm})$ physical and chemical properties prior to plot establishment (baseline), for biochar and FYM treatment and FYM only along with paired ' $t$ ' test significance for baseline compared to biochar + FYM and FYM only treatments

\begin{tabular}{llllll}
\hline Parameters & Baseline & Biochar + FYM & Significance $\dagger$ & FYM only & Significance $\S$ \\
\hline pH & $4.79 \pm 0.11 \mathrm{a}$ & $5.23 \pm 0.39 \mathrm{~b}$ & $*$ & $4.98 \pm 0.08 \mathrm{a}$ & NS \\
Soil Organic Matter (\%) & $2.018 \pm 0.512$ & $6.143 \pm 0.236$ & $* *$ & $6.43 \pm 0.08 \mathrm{~b}$ & $* *$ \\
Total Nitrogen (ppm) & $1274 \pm 108.44 \mathrm{a}$ & $1393 \pm 95.30 \mathrm{a}$ & $\mathrm{NS}$ & $1463 \pm 42.00 \mathrm{a}$ & $\mathrm{NS}$ \\
Available Phosphorus ( ppm) & $19.63 \pm 7.02 \mathrm{a}$ & $7.86 \pm 1.91 \mathrm{~b}$ & $*$ & $119.03 \pm 24.08 \mathrm{~b}$ & $* *$ \\
Exchangeable Potassium (ppm) & $176.08 \pm 109.1 \mathrm{a}$ & $264.73 \pm 75.73 \mathrm{~b}$ & $*$ & $194.80 \pm 52.93 \mathrm{a}$ & $\mathrm{NS}$ \\
Cation Exchange Capacity (m.e/100gm) & $17.00 \pm 4.13 \mathrm{a}$ & $22.24 \pm 2.74 \mathrm{a}$ & $\mathrm{NS}$ & $15.66 \pm 4.72 \mathrm{a}$ & NS \\
\hline
\end{tabular}

Means in the same rows followed by same letters are not significantly different at $\mathrm{p}<0.05$;

* Significant at $\mathrm{P}<0.05$; ** highly significant at $\mathrm{P}<0.01$; NS $=$ non significance

$\dagger$ Significance of paired t-test between baseline data and Biochar +FYM treatment

$\S$ Significance of paired t-test between Biochar +FYM and FYM only treatment

In case of the subsoil, SOM and EK increased significantly $(\mathrm{P}<0.05)$ after biochar and FYM addition to the soil. Similarly, pH, TN, AP and CEC increased slightly in biochar and FYM amended soils but not statistically significantly (Table 3 ).

In a similar manner, while comparing the sub-soil of biochar and FYM added and only FYM added plots; $\mathrm{pH}$, EK (not significantly), SOM and AP (significantly at $\mathrm{P}<0.05$ ) were higher after biochar and FYM addition were to the soil. Whereas, parameters such as TN (significantly at P<0.05), and CEC (not significantly) were higher in soil of the FYM only treatment (Table 3).

Table 3. Mean values $( \pm$ std. dev.) of sub soil $(15-30 \mathrm{~cm})$ physical and chemical properties prior to plot establishment (baseline), for biochar and FYM treatment and FYM only along with paired ' $t$ ' test significance for baseline compared to biochar + FYM and FYM only treatments

\begin{tabular}{lccccc}
\hline Parameters & Baseline & Biochar + FYM) & Significance $\dagger$ & FYM-only & Significance \\
\hline pH & $4.17 \pm 1.32 \mathrm{a}$ & $5.08 \pm 0.13 \mathrm{a}$ & $\mathrm{NS}$ & $4.72 \pm 0.34 \mathrm{a}$ & $\mathrm{NS}$ \\
Soil Organic Matter (\%) & $2.230 \pm 0.355$ & $6.040 \pm 1.010$ & $* *$ & $5.93 \pm 0.34 \mathrm{~b}$ & $* *$ \\
Total Nitrogen (ppm) & $964.26 \pm 311.1 \mathrm{a}$ & $1295 \pm 246.63 \mathrm{a}$ & $\mathrm{NS}$ & $1400 \pm 164.86 \mathrm{~b}$ & $*$ \\
Available Phosphorus ( ppm) & $20.23 \pm 12.23 \mathrm{a}$ & $102.97 \pm 51.70 \mathrm{a}$ & $\mathrm{NS}$ & $101.86 \pm 32.29 \mathrm{~b}$ & $*$ \\
Exchangeable Potassium (ppm) & $124.58 \pm 65.08 \mathrm{a}$ & $209.80 \pm 76.81 \mathrm{~b}$ & $*$ & $186.75 \pm 88.96 \mathrm{a}$ & $\mathrm{NS}$ \\
Cation Exchange Capacity (m.e/100gm) & $17.42 \pm 5.34 \mathrm{a}$ & $19.81 \pm 4.78 \mathrm{a}$ & $\mathrm{NS}$ & $20.94 \pm 3.34 \mathrm{a}$ & $\mathrm{NS}$ \\
\hline
\end{tabular}

Means in the same rows followed by same letters are not significantly different at $\mathrm{p}<0.05$; * significant at $\mathrm{P}<0.05$; ** highly significant at $\mathrm{P}<0.01 ; \mathrm{NS}=$ non significance.

$\dagger$ Significance of paired t-test between baseline data and Biochar + FYM treatment

$\S$ Significance of paired t-test between Biochar + FYM and FYM only treatment

\subsection{Effect of Biochar Amendment on Crop Growth}

Application of biochar at the rate of 5 t/ha to the soil in a coffee agroforestry system along with $20 \mathrm{t} / \mathrm{ha}$ FYM revealed statistically significant differences in crop growth at $(\mathrm{p}<0.05)$ in coffee, chilly and garlic growth, and highly significant differences $(\mathrm{p}<0.01)$ in radish and soybean growth in biochar treated plot compared to the control (Table 4). 
Table 4. Paired " $t$ " test of biochar effect on crop growth (height in $\mathrm{cm}$ )

\begin{tabular}{lllll}
\hline \multicolumn{4}{c}{ Mean Values } \\
\cline { 2 - 5 } Crop types & Treatment $\mathrm{n}=10$ & Control $\mathrm{n}=10$ & ' $\mathrm{t}$ ' value \\
\hline Coffee & 81.90 & 68.10 & $4.73^{* *}$ \\
Radish & 9.40 & 6.76 & $11.24 * *$ \\
Chilli & 91.20 & 68.50 & $-4.14 * *$ \\
Soybean & 42.60 & 28.50 & $6.80^{* *}$ \\
Garlic & 65.90 & 55.40 & $3.93^{* *}$ \\
\hline
\end{tabular}

Note: **highly significant at $\mathrm{P}<0.01$ level probability

\subsection{Plant Yield Kg per Plot/Ton per Hectare Influenced by Biochar Application}

Crop yield (kg per plot/ton per hectare) of all crops radish, soybean, chilly and garlic were observed to be relatively higher in biochar \& FYM amended soils in comparison to only FYM added soils. However, statistically significant differences were not observed (see Figure 3).

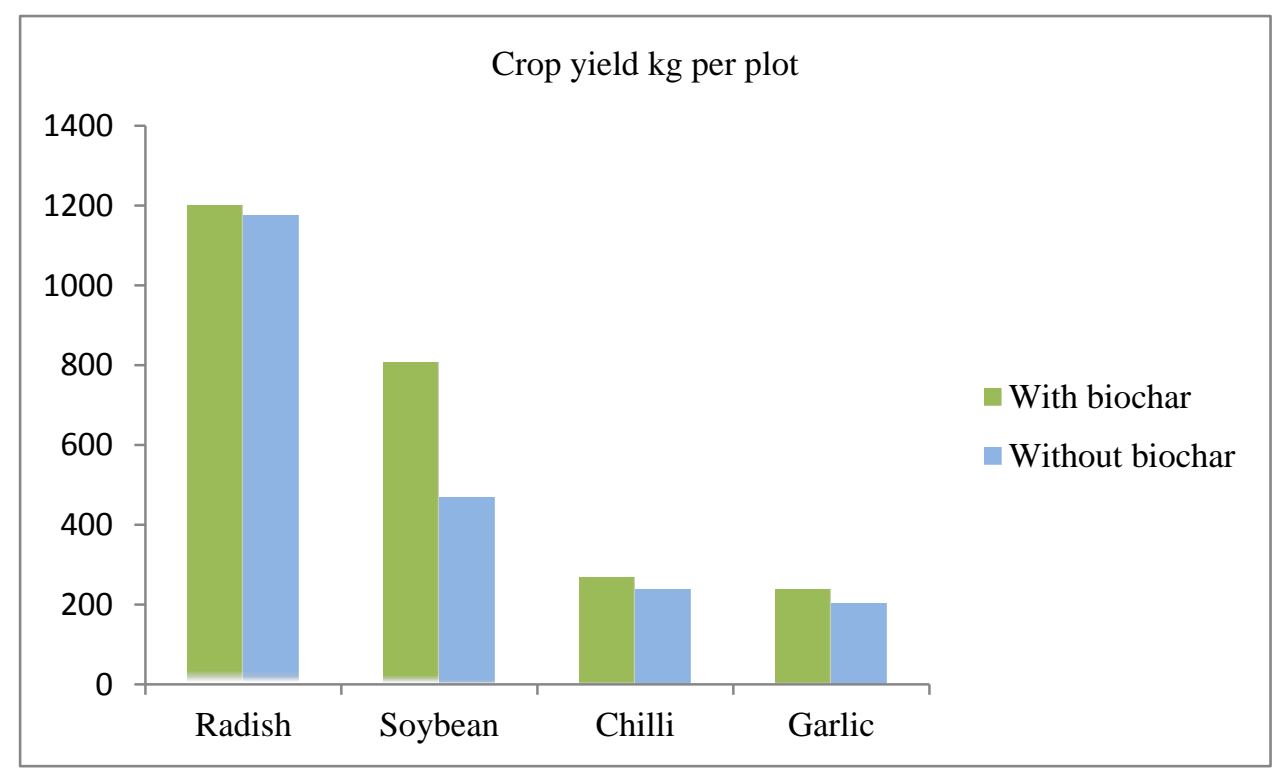

Figure 3. Plant yield (kg per plot) with and without biochar application

\section{Discussion}

\subsection{Soil Chemical Properties in Relation to Soil Depth}

Agroforestry system is a widely recognized farming practice having potential to maintain and improve soil fertility and nutrient cycling (Tian et al., 2013; Wang \& Cao, 2011). Soil fertility is the major yardstick to determine the level of soil physical and chemical properties of the soil which indicates the capacity of the soils to provide nutrients required by crops (Neupane, 2000). Soil chemical properties evaluation was based on the laboratory analysis of major soil variables such as $\mathrm{pH}$, soil organic matter, total nitrogen, available phosphorus, exchangeable potassium and cation exchange capacity.

As seen from the baseline soil data (Tables 2 and 3$)$ it is evident that the top soil $(0-15 \mathrm{~cm})$ and sub-soil $(15-30$ $\mathrm{cm}$ ) in this field experiment were of a degraded clay soil with chemical properties generally in the low range for commercial crop production. In the case of the top soil, it was observed that after the application of biochar and FYM, soil parameters, namely, $\mathrm{pH}$, EK and SOM were increased significantly, while, TN and CEC increased slightly, but without statistical differences. In contrast AP decreased significantly compared to the control, which could be due to $\mathrm{P}$ adsorption by biochar as well as more effective crop uptake.

In both top soil and sub soil, increase in $\mathrm{pH}$ was observed in the biochar amended soil compared to the baseline values and the FYM only control treatment. This was evidently due to the alkaline nature of biochar (Barrow, 2012) which, upon addition to the soil could have contributed towards reducing the acidity. However, the increase was, expectantly, not significant in the sub soil, which was due to the application of low rates of biochar 
and tillage (incorporation) only within the top $15-20 \mathrm{~cm}$ of soil.Moreover, addition of the organic manure could have resulted in nitrification which releases protons to the soil ( Brewer et al., 2012).

In contrast, there was a significant decrease in phosphorus availability in biochar amended top soil. In this case, the biochar might have acted as a sink rather than source of $\mathrm{P}$ as it may have been adsorbed to the biochar particles. Similar results of decrease in water soluble phosphorus has been observed in a silty clay loam soil at $1 \%$ (w/w) biochar application (Parvage, Ulén et al., 2013). In the case of the subsoil, the above mechanism of adsorption by biochar was likely insignificant as the biochar was applied only to the surface layer. Also, mineralization of organic matter in the soil could have occurred which is greatly dependent upon the temperature and moisture level of the soil (Qadeer \& Batool et al., 2014) and might have acted as a source in this case.

\subsection{Plant Growth As Affected By Application of Biochar and FYM}

It was noted that after the application of biochar along with FYM to the soil, plant growth (height) was significantly higher in treated plots than the control. This was attributed to the effect of biochar on soil, which largely influence the accumulation of SOM and improves other soil chemical properties, such as $\mathrm{pH}$, which ultimately enhanced the quality and productivity of degraded and low quality soils, similar finding that have been reported by Khan et al., (2013) and Bajracharya et al., (2015). Likewise Scislowska et al., 2015 documented that the application of biochar to soils had positive effects on plant growth by improving soil nutrient availability, water holding capacity, carbon sequestration, CEC and soils $\mathrm{pH}$ level. Thus, biochar appears to have rapid effect in enhancing the vegetative growth of crops in the short-run.

\subsection{Influence of Biochar and FYM on Crop Yields}

The results of this study indicated that while the application of biochar along with FYM to degraded soil in a hill agroforestry system generally increased the yields for a number of vegetables, intercropped with coffee, the yields were not statistically different in the short term. However, it was observed that the yield of soybean was markedly higher than that of other crops. This could be due to the nitrogen fixing effect of the leguminous soybean crop. It could, however, be said that the effect of biochar amendment on crop yield improvement is likely to seen only in the long-term as the overall soil quality gradually improves.

\section{Conclusions}

The results of this study indicated that a significant improvement in some soil properties (SOM and $\mathrm{pH}$ ), crop growth rate (height) and productivity could be attributed to the effect of biochar and FYM application on a degraded soil in a coffee agroforestry system. While it was noted that biochar applied at low rates along with FYM generally has immediate positive effects on the vegetative growth of plants, soil properties and overall crop yields may, however, take a longer time to show improvement. Future long-term research is needed to confirm the benefits of biochar amendment on soil quality and crop yields and productivity.

\section{Reference}

Alburquerque, J. A., Salazar, P., Barrón, V., Torrent, J., del Campillo, M. D. C., Gallardo, A., \& Villar, R. (2013). Enhanced wheat yield by biochar addition under different mineral fertilization levels. Agronomy for Sustainable Development, 33(3), 475-484. https://doi.org/10.1007/s13593-012-0128-3

Bajracharya, Roshan M., \& Dil Prasad, Sherchan. (2009). Fertility status and dynamics of soils in the Nepal Himalaya: a review and analysis. Soil Fertility, 111-135.

Bajracharya, R. M., Atreya, K., Raut, N., Shrestha, H. L., Gautam, D. K., \&Dahal, N. R. (2015). Sustainable Diversified Agriculture and Land Management in the Himalaya: Implications for climate change adaptation and mitigation. In Paper presented at the International Conference on Mountains and Climate Change, 16, 18.

Baker, D. E., \& Amacher, M. C. (1982). Nickel, Copper, Zinc and Cadmium. IN: A. L., Miller, R. H., Keeney, D.R. (Editors). Methods of Soil Analysis Part 2 (2nd edition), Chemical and Microbiological Properties, Monograph No. 9, ASA-SSSA, Madison, WI, USA. P. 323-334.

Balla, M. K., Tiwari, K. R., Kafle, G., Gautam, S., Thapa, S., \& Basnet, B. (2014). Farmers dependency on forests for nutrients transfer to farmlands in mid-hills and high mountain regions in Nepal (case studies in Hemja, Kaski, Lete and Kunjo, Mustang district). International Journal of Biodiversity and Conservation, 6(3), 222-229. https://doi.org/10.5897/IJBC2013.0670

Barrow, C. J. (2012). Biochar: potential for countering land degradation and for improving agriculture. Applied Geography, 34, 21-28. https://doi.org/10.1016/j.apgeog.2011.09.008 
Bingham, F. T., Boron, A. L., Miller, R. H., \& Keeney, D. R. (Eds). (1982). Methods of Soil Analysis Part 2 (2nd edition), Chemical and Microbiological Properties, Monograph No. 9, ASA-SSSA, Madison, WI, USA. 431-443.

Blake, G. R., \& Hartge, K. H. (1986). Bulk density.In: page, A.L. (eds). Methods of soil analysis part 1 (2 ${ }^{\text {nd }}$ edition) physical and mineralogical methods agronomy monographs. ASA; SSSA. Madison. WI, USA, 425-442.

Bremner, J. M., \& Mulvaney, C. S. (1982). Nitrogen Total. In:A. L. Page, R. M. Miller and D. R. Keeney, (eds.) Methods of soil analysis Part 2 ( $2^{\text {nd }}$ edition $)$ Chemical and Microbiological Properties. American Society Agronomy Monograph No. 9, ASA-SSSA, Inc., Madison, WI, USA, 595-610.

Deal, Christopher, Catherine, E., Brewer, Robert, C., Brown, Mackay, AE Okure, \& Alice, Amoding. (2012). Comparison of kiln-derived and gasifier-derived biochars as soil amendments in the humid tropics. Biomass and bioenergy, 37, 161-168. https://doi.org/10.1016/j.biombioe.2011.12.017

Gambrell, R. P., \& Ellis, Jr., R. (1982). Manganese, IN: A. L., Miller, R. H., Keeney, D.R. (Editors). Methods of Soil Analysis Part 2 (2nd edition), Chemical and Microbiological Properties, Monograph No. 9, ASA-SSSA, Madison, WI, USA. 313-322.

Gee, Glendon, W., \& James W. Bauder. (1986). Particle-size analysis. Methods of soil analysis: Part 1-Physical and mineralogical methods methodsofsoilan1, 383-411.

Kandji, Serigne T., Louis V. Verchot, Jens Mackensen, A. Boye, M. Van Noordwijk, T. P. Tomich, C. K. Ong et al. "Opportunities for linking climate change adaptation and mitigation through agroforestry systems." World Agroforestry into the Future. World Agroforestry Centre, ICRAF, Nairobi, Kenya (2006): 113-121.

Khan, Naseem, Zahir Shah, Nazeer Ahmed, Saeed Ahmad, Nasir Mehmood, \& Muhammad Junaid. (2013). Effect of integrated use of biochar, FYM and nitrogen fertilizer on soil organic fertility. Pure and Applied Biology, 2(2), 42. https://doi.org/10.19045/bspab.2013.22001

Knudsen, D., Peterson, G. A., \& Pratt, P. F. (1982). Potassium. In: A. L., Miller, R. H., Keeney, D.R. (Editors). Methods of Soil Analysis Part 2 (2ndedition), Chemical and Microbiological Properties, ASA/SSSA, In. Madison.USA. 225:246.

Lehmann, J., \& Joseph, S. (eds.) (2015). Biochar for environmental management: science, technology and implementation. Routledge.

Lin, B. B. (2014). Agroforestry adaptation and mitigation options for smallholder farmers vulnerable to climate change. In Agroecology, Ecosystems, and Sustainability (pp. 221-238). CRC Press. https://doi.org/10.1201/b17775-12

MacLeod, C. J., \& Moller, H. (2006). Intensification and diversification of New Zealand agriculture since 1960: An evaluation of current indicators of land use change. Agriculture, ecosystems \& environment, 115(1), 201-218. https://doi.org/10.1016/j.agee.2006.01.003

Mekuria, W., \& Noble, A. (2013). The role of biochar in ameliorating disturbed soils and sequestering soil carbon in tropical agricultural production systems. Applied and Environmental Soil Science, https://doi.org/10.1155/2013/354965

Nair, P. K. R. (2012). Carbon sequestration studies in agroforestry systems: a reality-check. Agroforestry Systems, 86(2), 243-253. https://doi.org/10.1007/s10457-011-9434-z

Nelson, D. W., \& Sommers, L. (1982). Total carbon, organic carbon, and organic matter. Methods of soil analysis. Part 2. Chemical and microbiological properties, (methodsofsoilan2), 539-579.

Neupane, R. P. (2000). Prospects of agroforestry promotion in the hills of Nepal (Unpublished doctoral thesis). Asian Institute of Technology, Thailand.

Novak, Jeffrey, M., Warren, J. Busscher, Donald, W. Watts, James, E., Amonette, James, A., Ippolito, Isabel, M. Lima, Julia Gaskin et al. (2012). Biochars impact on soil-moisture storage in an ultisol and two aridisols. Soil Science, 177(5), 310-320. https://doi.org/10.1097/SS.0b013e31824e5593

Olson, R.V. and Ellis Jr., R. 1982 Iron. IN: Miller, R. H., Keeney, D.R. (Editors). Methods of Soil Analysis Part 2 (2nd edition), Chemical and Microbiological Properties, Monograph No. 9, ASA-SSSA, Madison, WI, USA. 301-312.

Parvage, Mohammed Masud, Barbro Ulén, Jan Eriksson, Jeffery Strock, and Holger Kirchmann. (2013). 
Phosphorus availability in soils amended with wheat residue char. Biology and fertility of soils, 49(2), 245-250. https://doi.org/10.1007/s00374-012-0746-6

Pastur, Guillermo Martínez, Emilie Andrieu, Louis R. Iverson, \& Pablo Luis Peri. (2012). Agroforestry landscapes and global change: landscape ecology tools for management and conservation. Agroforestry systems, 85(3), 315-318. https://doi.org/10.1007/s10457-012-9496-6

Qadeer, Samia, Aniqa Batool, Audil Rashid, Azeem Khalid, Nafeesa Samad, \& Muhammad Asad Ghufran. (2014). Effectiveness of biochar in soil conditioning under simulated ecological conditions. Soil \& Environment, 33(2).

Rhoades, J. D. (1982). Cation Exchange Capacity.In:A. L. Page, R. M. Miller and D. R. Keeney, eds. Methods of Soil Analysis Part $2\left(2^{\text {nd }}\right.$ edition$)$ Chemical and Microbiological Properties, American Soc. of Agron. Monograph No. 9, ASA-SSSA, Inc., Madison, WI, USA, 149-158.

Rasul, Golam, \& Gopal B. Thapa. (2004). Sustainability of ecological and conventional agricultural systems in Bangladesh: an assessment based on environmental, economic and social perspectives. Agricultural systems, 79(3). 327-351. https://doi.org/10.1016/S0308-521X(03)00090-8

Roshetko, James M., E. Nugraha, J. C. M. Tukan, G. Manurung, C. Fay, \& Van Noordwijk, M. (2007). Agroforestry for livelihood enhancement and enterprise development. In ACIAR PROCEEDINGS, 126, 137. ACIAR; 1998.

Schreier, H., Shah, P. B., Lavkulich, L. M., \& Brown, S. (1994). Maintaining soil fertility under increasing land use pressure in the Middle Mountains of Nepal. Soil use and Management, 10(3), 137-142. https://doi.org/10.1111/j.1475-2743.1994.tb00474.x

Ścisłowska, Mariola, Renata Włodarczyk, Rafał Kobyłecki, \& Zbigniew Bis. (2015). Biochar to improve the quality and productivity of soils. Journal of Ecological Engineering, 16(3). https://doi.org/10.12911/22998993/2802

Steiner, Christoph, Wenceslau G. Teixeira, Johannes Lehmann, Thomas Nehls, Jeferson Luis Vasconcelos de Macêdo, Winfried EH Blum, \& Wolfgang Zech. (2007). Long term effects of manure, charcoal and mineral fertilization on crop production and fertility on a highly weathered Central Amazonian upland soil. Plant and soil, 291(1-2), 275-290. https://doi.org/10.1007/s11104-007-9193-9

Swanepoel, Pieter A., Philip R. Botha, Chris C. du Preez, Hennie A. Snyman, \& Johan Labuschagne. (2015). Managing cultivated pastures for improving soil quality in South Africa: challenges and opportunities. African Journal of Range \& Forage Science, 32(2), 91-96. https://doi.org/10.2989/10220119.2015.1051112

Tiwari, Krishna, R., Bishal K. Sitaula, T. Borresen, \& Roshan M. Bajracharya. (2006). An assessment of soil quality in Pokhare Khola watershed of the Middle Mountains in Nepal. Journal of Food Agriculture and Environment, 4(3/4), 276.

Wang, Guibin, \& Fuliang Cao. (2011). Integrated evaluation of soil fertility in Ginkgo (Ginkgo biloba L.) agroforestry systems in Jiangsu, China. Agroforestry systems, 83(1), 89. https://doi.org/10.1007/s10457-011-9399-y

Yu, Ok-Youn, Brian Raichle, \& Sam Sink. (2013). Impact of biochar on the water holding capacity of loamy sand soil. International Journal of Energy and Environmental Engineering, 4(1), 44. https://doi.org/10.1186/2251-6832-4-44

\section{Copyrights}

Copyright for this article is retained by the author(s), with first publication rights granted to the journal.

This is an open-access article distributed under the terms and conditions of the Creative Commons Attribution license (http://creativecommons.org/licenses/by/3.0/). 